Kaygl, 19(II)/2020: 590-610. Araştırma Makalesi | Research Article

Makale Geliş | Received: 13.02.2020

Makale Kabul | Accepted: 15.08.2020

Yayın Tarihi | Publication Date: 15.09.2020

DOI: 10.20981/kaygi.790368

Recep AKGÜN

Dr. Öğr. Üyesi | Assist. Prof. Dr.

Karamanoğlu Mehmetbey Üniversitesi, Edebiyat Fakültesi, Sosyoloji Bölümü, Karaman, TR Karamanoglu Mehmetbey University, Faculty of Literature, Sociology Department, Karaman, TR

ORCID: 0000-0001-5944-4544

recocemalakgun@gmail.com

\title{
Pierre Bourdieu's Theory of Culture and the Possibility of Social Change
}

\begin{abstract}
This article critically analyzes Pierre Bourdieu's ideas on the social change in the context of his sociology of culture. Around this analysis the study presents how Bourdieu places social change in his sociology of culture and shows his theoretical possibilities and limitations about the change within the social. Thus, it is claimed that Bourdieu's sociology of culture inserts the agency into the cultural analysis to open a space for the change within the social through assigning an active role to the agents vis-a-vis objective social conditions and structures, however, his ideas on agency delimits the scope of change in the social. Correspondingly, the study sets forth the possibilities and limitations of theory of social change in Bourdieu's sociology of culture critically by means of examining his general theoretical procedures and ideas on the social.
\end{abstract}

Keywords: Pierre Bourdieu, Sociology of Culture, Social Change, Agency, Habitus.

\section{Pierre Bourdieu'nun Kültür Sosyolojisi ve Toplumsal Değişim İhtimali \\ $\ddot{O} \mathbf{z}$}

Bu makale kültür sosyolojisi bağlamında Pierre Bourdieu'nun toplumsal değişim üzerine fikirlerini eleştirel olarak analiz eder. $\mathrm{Bu}$ analiz etrafında Bourdieu'nun toplumsal değişimi kültür sosyolojisine nasıl yerleştirdiğini ortaya koyar ve onun toplumsallıktaki değişime dair kuramsal olanaklarını ve sınırlılıklarını gösterir. Bu açıdan, Bourdieu'nun kültür sosyolojisi nesnel toplumsal koşullar ve yapılar karşısında faillere aktif bir rol yükleyerek, toplumsalıkta değişime alan açmak için failliği kültür analizine dahil ettiği, fakat onun faillik üzerine fikirleri toplumsallığın değişiminin kapsamını sınırladığı iddia ediliyor. Buna bağlı olarak, çalışma Bourdieu'nun toplumsal üzerine genel kuramsal prosedürlerini ve fikirlerini eleştirel bir biçimde analiz ederek, onun kültür sosyolojisinde toplumsal değişimin olanaklarını ve sınırlılıklarını ortaya koyar.

Anahtar Kelimeler: Pierre Bourdieu, Kültür Sosyolojisi, Toplumsal Değişim, Faillik, Habitus. 


\section{Introduction}

Pierre Bourdieu discusses the sociological topics and facts through a new methodology and theory which seeks to undo the dualities within sociological thought, such as agency-structure, subjectivity-objectivity, and individual-social. One of the topics within the discipline of sociology that Bourdieu concentrated upon is culture. Ideas of Bourdieu about culture offer new ways of reading and analyzing the cultural field framed by his general sociological and philosophical views on the subjectivity and the social. At first glance, the ideas of Bourdieu about the cultural product seem to be parallel with the Marxist thinking on the culture and cultural product from Theodor Adorno \& Max Horkheimer (Adorno\&Horkheimer: 2000), György Lukacs (Lukacs, 1988), and Antonio Gramsci (Gramsci: 2003) to Louis Althusser (Althusser, 2014), Henry Lefebvre (Lefebvre, 1991) and Guy Debord (Debord, 1995). These thinkers place their reading and analysis on the cultural product into the political and sociological contexts. These thinkers do not treat the cultural products per se; they concentrate on the function and role of the cultural product to produce and maintain the power relations in capitalist society through the very ideological operation of the cultural products. According to this framework, the cultural products are not merely the direct passive effect of economic relations but have a force to maintain the dominant order, even if the economic processes pave the way for the production processes of the cultural product. From a schematic and generalizing point, it is barely that they analyze, read, and interpret the cultural products concentrating upon the role of the production mechanisms and processes. That is to neglect the consumption processes of cultural production and their effects in the case of Adorno \& Horkheimer, Lefebvre, and Debord. Arriving from views of Michel de Certeau, it becomes evident that these thinkers analyze the cultural products from the point of production overlooking the processes of the usage of the cultural products (de Certeau, 1988). Therefore, they neglect the role of the consumers and receivers of the cultural products to form and construct the cultural field. 
However, Bourdieu's reading of culture and cultural products differentiate from the ideas and methods of these thinkers and analyzers, since he places his analysis and interpretations both in the consumption and production processes of the cultural products. These processes are not given, but the product of the social space in which different positions emerge through their relationships with each other; the product of the dialectical relationship between social structures and habitus at a given time and space. Different social positions and classes have different ways of consumption and production. This perspective is framed by his philosophical views on art and culture according to which he historicizes and socializes phenomena and ideas.

Here, he tries to develop a sociology of the cultural products and culture analyzing usages of the cultural products by different classes to expose the historical and social elements constructing ideas and practices. Given these, this study deals with Bourdieu's ideas about the consumption and production process of the cultural product. The study will mainly turn around how Bourdieu reads and places the cultural product in the sociological ground. This reading and analysis include ideas on social change. Therefore, this study will discuss Bourdieu's ideas on the social change around his ideas on culture.

Bourdieu's sociology of culture mainly turns around the idea of analyzing the determinants of all human actions concentrating upon the social and historical as he does in Distinction (Bourdieu, 1996) and The Production of Cultural Field (Bourdieu, 1993). However, these determinants are not the result of passive internalization of objective rules. His main problem is to link subjective and objective and structure to the agency. On the one hand, he approves the role of objective structures or langue to construct the practices of agents; on the other hand, he argues that the social space is not mechanically one to one imitation of the structures or langue. Correspondingly, he offers to look at actual usages of the structures or langue or internalization processes of the objective rules. Henceforth, Bourdieu attempts to solve the problem of Althusser's ideas on interpellation (Althusser, 2014). Moreover, he points out the gap in Foucault's ideas on the power to link the subject and power in the context of processes of 
construction of subjectivities by power (Foucault, 1977; 1980). According to him, social space is not a strict space as it is closed to the intervention of the agents' practices but are produced and reproduced through the agents' active existence. Around these ideas, Bourdieu seems to open a space for social change (Bourdieu, 1998). However, the production and reproduction of the structures by agents are very related to their habitus, which is the incorporation of the structures and given social positions, even if agents can change the content of the game through constructing another position or reappropriating these positions with their way of producing and consuming. However, these changes in the contents of the structures and positions don't go beyond the boundaries and rules of the game. For instance, people's tastes are the product of the positions and position-takings. These positions are the expression of the constructed and symbolically legitimized inequalities and dominance relations.

These ideas are beneficial in explaining the workings of power relations, attempting to think beyond the symbolically constructed dualities and their correspondences in the actual life producing the domination. However, Bourdieu's thought doesn't leave a chance for the change within the system, even if the system is continually changing. Because his explanations are anchored only into spatial metaphors and do not mention time, thus, he uses the strategic possibilities but not tactics of the people. As space replaces time, strategic possibilities replace the tactics whose different modes can come together and create connections to create strategic actions or destruct the structures to create new modes of production. In that sense, this study argues that Bourdieu's sociology of culture is nihilistic and pessimistic about social change, even if he reveals the constructed nature of the power relations and their legitimization through the construction of doxas.

The study, firstly, briefly explains his philosophical ideas that attempt to criticize "the substantialist mode of thought," and sociological methodology that is the transcendent dualities project, such as objectivism and subjectivism, and habitus and structure. The second section makes clear the concepts like habitus, structure, and social field. All these philosophical and sociological ideas argue that all phenomena of art and 
culture in human life have a social determination and must be placed within social history. In that sense, he tries to read the cultural products not as signs as formalism did, but as the product of the social space of which the cultural field is the part through concentrating upon the production and consumption processes of the cultural products. Thus, the third section of this study talks about the production of the cultural field. Fourth section approaches the consumption of the cultural products by different social classes. Bourdieu's concentration upon class distinctions through analysis of various lifestyles in Distinction in the case of taste is the focus of this section. This section discusses the class nature of the consumption processes. According to Bourdieu, every class has a unitary lifestyle, which is the product of their class positions. However, legitimate culture assumes that their way of life is because of their innate nature. So, dominant classes try to naturalize the distinctions through producing the symbolic distinction. The dominated classes also approve these distinctions. In that sense, the dominated classes internalize these power relations with complicity, as long as they do not go beyond the dominant classes' feelings and viewpoints. In that sense, this last section will offer to clarify Bourdieu's ideas on doxa, class, and distinction.

\section{Transcending the Dualities: The Methodological Attempt of Bourdieu}

As mentioned above, Bourdieu's sociology is related to his philosophical project to historicize and socialize philosophy, implying that all concepts and ideas in philosophy and thinking are the product of the material interests of the individuals who are the product of the social. Thus, as he argues in The Logic of Practice, any thought, conceptualization, or idea about the material world has no transcendental status, but merely applies abstract categories onto the actual world (Bourdieu,1990). Also, there is no philosophical idea and conceptualization beyond the positions of the thinkers. As he interrogates, there is a reason and social determination to use any discourse and study any subject. In this context, he objects to Kant's idea that all epistemological and aesthetical categories are ahistorical. In that sense, he maintains a tradition from Leibniz, Hume, Nietzsche, and Marx who tried to historicize, socialize and materialize 
the mind, aesthetics, and beauty from different viewpoints. Thus, for Bourdieu, what makes a piece of art beautiful and makes information correct is very related to social positions. For Bourdieu, any abstract category, idea, and conceptualization is not naturally given but is related to the interests of the agents. In other words, the disinterestedness which makes episteme and judgments objective is a myth. In Nietzschean terms, all ideas are nothing other than the symptoms of forces, and all thoughts are metaphorical categories imposed into reality. Thus, interests and unconscious mechanisms that are the product of socialization determine the positions and position taking in scientific and philosophical points of view.

In this context, Bourdieu offers a sociological reading of ideas and aesthetic judgments. But this reading is very parallel to his epistemology, which is the criticism of objectivism and structuralism and also of subjectivism, according to which he attempts to transcend the methodological and conceptual dualities in sociology. Neither of these approaches considers lived experience but impose abstract categories on it as if their categories and ideas are exempt from their social positions. Thus, he offers "a critical objectification of the epistemological and social conditions that make a reflexive return to the subjective experience of the world and the objectification of the objective conditions of that experience."(Bourdieu, 1990: 25) On this ground, he objects to the objectivist outlook that gives priority to objective structures. He also criticizes and the subjectivist perspective that gives priority to the agency. In parallel to this, he both objects to structuralism and historicism in their views about the construction of the social. The quotation below summarizes his viewpoint:

of all the oppositions that artificially divide social science, the most fundamental, and the most ruinous, is the one that is set up between subjectivism and objectivism...To move beyond the antagonism between these two modes of knowledge, while preserving the gains from each of them (Bourdieu, 1990: 25)

In that sense, Bourdieu criticizes subjectivism, because it emphasizes the autonomy of the agents from the social structures. On the other hand, for him, the structuralism assumes the primacy of logic and structure over individual and collective 
history or gives priority to structural analysis over external and social determinations. In that sense, he probably tries to open a space for agency. However, subjects are neither entirely free nor determined by the social structures. For this project, he inserts the term habitus, which is "the systems of durable, transposable dispositions, structured structures predisposed to function as structuring structures, that is, as principles which generate and organize practices and representations..." (Bourdieu, 1995: 53). So, social structures are activated by agents who have different habitus.

These points in Bourdieu's thought barely express that, on the one hand, he offers to examine the objective structures as structuralism does, and on the other hand, he contends that agents are not passive concerning objective rules of society. However, the objective structures are neither ahistorical nor are the subjects fully free vis-a-vis structures. These ideas are very evident in his criticism of structuralist linguistics. According to him, Saussure concentrates on objective grammatical structures or langue in parallel with his objectivism, which excludes speaking in which agents' actual usage of a language can be seen (Bourdieu, 1991: 32-34). Therefore, structuralism is concerned with the ahistorical objective structures, excluding the practices of the agents. Thus, structuralist semiology assumes that language is exempted from power struggles. In other words, structuralism gives the language a neutral character because it tends to look only at objective structures. For Bourdieu, structuralism's attitude towards the language is grounded upon an objectivist outlook that imposes the concepts as if these concepts are purely abstract and not the choices of the scholars as being the products of their social positions (Bourdieu, 1990). In that sense, Bourdieu offers to treat the parole or speaking where is the site of the social and language becomes the arena for the struggles in parallel with Voloshinov's ideas on language (Voloshinov, 1973). Such a perspective can be read as the strategy to open a space for the agents. However, this strategy doesn't argue that there are no objective structures in society, and agents create the language with free choices, as subjectivism argues. Instead, society is the product of the dialectical relationship between the objective structures and subjective strategic possibilities. As he emphasizes, the social is the product of the dialectical relationship 
between the habitus, which is the dispositions of agents towards the external world and structures in which the agents were born.

This is why Bourdieu objects to semiology, which reads human actions as signs reducing the complexity of the human practices to abstract categories. Instead, Bourdieu offers to examine the social grounds of human actions. He doesn't say that human practices are exempted from social structures because the agents' production is the result of their interaction with structured structures. That position places human actions into the social field in which the social determinants of the theoretical and practical actions can be considered. As a result, he offers to look at the social field to read the cultural actions and products, which includes the consumption and production processes in which the dialectical relationship between agents and structures can be seen. Thus, the next section explains his ideas on the relationship between habitus, structure, and social field.

\section{Structure, Habitus and Field}

For Bourdieu, all human actions emerge within social fields. As mentioned in the third section, these fields consist of positions and position takings. In that sense, the agents are born into a society that has objective positions. However, the agents don't passively internalize the social structures and positions. Instead, the agents strategically choose the possibilities in the field due to having an active force. These strategic choices are very related to the habitus of agents. "The habitus, a product of history, produces individual and collective practices- more history- in accordance with the schemes generated by history." (Bourdieu, 1995:54). In that sense, the habitus provides the individuals with the schemes of action and dispositions in all social practices. In that sense, the habitus can be a structural system inscribed in the individuals through the internalization of society's objective rules. What constitutes habitus is related to the class backgrounds of the persons: "The conditionings associated with a particular class of conditions of existence produce habitus, systems of durable, transposable dispositions, structured structures predisposed to function as structuring structures, that 
is, as principles which generate and organize practices and representations..."(Bourdieu, 1995: 53). Therefore, the person's habitus determines the choices of the individuals because the habitus operates an unconscious element. In other words, the habitus determines the capacities of an individual in social life.

So, on the one hand, it is clear that agents have a chance to develop in the social space through choosing strategic possibilities; on the other hand, the habitus determines their actions because it donates the individuals with schemes of perception and action within the social life. In other words, the dispositions of the persons are very compatible with the individuals' objective conditions. "In reality, the dispositions durably inculcated by the possibilities and impossibilities, freedoms and necessities, opportunities and prohibitions inscribed in objective conditions...generate dispositions objectively compatible with these conditions and in a sense preadapted to their demands." (Bourdieu, 1995: 54).

What determines the actions of the agents are very related to the dialectical relationship between habitus and the objective conditions within the social space. For this reason, the habitus determines the actions of the persons unconsciously contrary to the idea that the persons are fully free in their actions; on the other hand, the agents have no choice in social space. In that sense, these views are both the criticism of objectivism and a substantialist mode of thinking. As the former makes the agents passive and neutralize the objective structures, the later make the agents conscious and their properties the gift of nature.

Given these, the social space constructs the differences among the agents according to their habitus. ${ }^{1}$ This fact reveals the class nature of the social space. In other

\footnotetext{
${ }^{1}$ The stratification of social space, according to the differences, is formed by the capital possessed by any agent. Bourdieu differentiates different kinds of capital belonging to various social fields. These are social, symbolic, cultural, and economic capitals. However, the number of forms of capital is not limited to four. Apart from them, there are religious, political, or bureaucratic capitals. There are as many forms of capital as fields. Each capital provides an agent with the capacities and ways of action to exist in any social field. One gains the capital during the lifetime of any agent. Thus, the social background may determine what type of and the extent of capital one has. For example, suppose an agent is a member of a working-class family against consuming the bourgeois high culture products, and her cultural habitus is structured along with the taste of the family's tastes. In that case, she may have no capital to exist in the
} 
words, the individual exists within a social space, which is constructed through the oppositions between different classes. In that sense, in the social space, all actions bear the trace of the constructed differences:

This idea of difference, or a gap, is at the basis of very notion of space, that is a set of distinct and coexisting positions which are exterior to one another and which are defined in relation to one another through their mutual exteriority and their relations of proximity, vicinity, or distance, as well as through relations of order, such as above, below, and between (Bourdieu, 1998: 6).

For Bourdieu, every human action bears the mark of the distinctions between the positions and position takings in the social field. In that sense, the cultural production and consumption of the cultural products are grounded upon constructed positions and position takings in the social field. Thus, the production and consumption of any cultural product is not the result of naturally given properties of the individuals and, therefore, neutral. The actions of individuals are very related to their capacity to act, which is the result of the distribution of different capitals. Rather as he tries to show in Distinction and The Production of Cultural Field, every action of the producers and consumers is the product of the dialectical relationship of the dispositions and objective structures. In that sense, agents' practices emerge within a social field existing with a position and position-taking according to their dispositions.

These ideas make the social and actions of the individual products of class differences and the struggles between different class positions. However, classes are not homogeneous units, and class formation is not only related to the distribution of economic capital, but also to the distribution of symbolic, social, and cultural capital. Because habitus creates the capacity of an individual in the social field, it is constituted by the distribution of these different capitals. Also, as he showed in Distinction, different individuals of the same class can have different manners because of their

cultural field, if the bourgeois high culture dominates the cultural. Thus, the capital has a role in forming the stratification in the social fields. If an agent has a capital conforming to the dominant positions in any social field, she can find a dominant position. Conversely, as long as an agent has a capital compatible with the dominant positions, the agent can only settle in a subordinate position. Given these, any agent's capital determines which position of any agent can have in any social field. 
different habitus. This class background of the actions of everything in social life makes the individuals' actions existing within the schemes and classifications, making the lifestyles of the persons coherent and accorded. For Bourdieu, the lifestyles of the individuals can be classified according to class distinctions:

The habitus is both the generative principle of objectively classifiable judgments and system of classification (principium divisions) of these practices. It is in the relationship between two capacities which define the habitus, the capacity to produce classifiable practices and works, and to capacity to differentiate and appreciate these practices and products (taste), that the represented social world, i.e., the space of lifestyles, is constituted (Bourdieu, 1996: 170).

Not only lifestyle, which includes the consumption of cultural products, but also the production of any cultural product is related to the generation of the habitus in the social field. His views on the cultural field and lifestyles exemplify his general opinions on the relationship between the social field, habitus, and social structures. Therefore, the next section examines his views on the production of the cultural field.

\section{The Field of Cultural Production: Historicalization and Socialization of the Aesthetics}

In The Field of Cultural Production Bourdieu primarily strives to relativize and historicize cultural products' meaning and beauty. He deals with how perception, affection, senses, feeling, perception, and taste are socially constructed. Thus, social history and sociology are beneficial as a means to develop a critical stand against taking truth and beauty as ahistorical and coherent a priori unities:

Science can attempt to bring representations and instruments of thought - all of which lay claim to universality, with unequal chances of success - back to the social conditions of their production and of their use, in other words, back to the historical structure of the field in which they are engendered and within which they operate. According to the methodological postulate ... one is led to historicize these cultural products, all of which claim universality. But historicizing them determined state of the field of struggle; it also means restoring to them not only relativizing...it also means restoring them necessity by removing them from indeterminacy... (Bourdieu, 1993: 263). 
On that ground, he develops the term of the cultural field. The cultural field's conceptualization differentiates him from internal readings and previous external readings because he includes the social and historical to his reading. The cultural field is a social space constituted by the struggles of agents in opposition to each other to gain recognition, legitimacy, and believability. Every agent's existence is determined by the position and position taking in which the artist makes a place with him. The cultural field consists of producers and other agents such as art dealers, art sellers, art critics, and spectators. Thus, any cultural product's characteristics are not only the production of the producers but also of other agents and elements of the field. So, Bourdieu's argument, the cultural universe is the constitution of social networks, does not merely make the cultural universe the effect of economics and politics. He argues that the cultural field has laws that make it independent: "...a field is a separate social universe having its own laws of functioning independent of those of politics and economy." (Bourdieu, 1993: 162). Thus, he criticizes the Lukacsian and Goldmanian idea that the artist is the spokesman of his or her class, meaning that economics and politics determine the cultural field. It is irrelevant to search for a cause external to the art field because the field of art is intrinsically social.

On the one hand, he objects the text's internal reading, excluding social conditionings as structuralists, post-structuralists, and formalists do. On the other hand, he criticizes the external readings, because they consider the cultural field causally determined by economic and political forces. However, he is very close to internal readings and external readings in the context of the philosophical ground that any cultural product's characteristic is not the product of a creative artist. In other words, he objects to the writer's image as he or she is a transcendental and unique person, and his creation comes from some divine forces.

Accordingly, he emphasizes a need to make a "radical break with the substantialist mode of thought foreground the individual or the visible interactions between individuals, at the expense of structural relations between social positions." (Bourdieu, 1993: 29). As a result, Bourdieu proposes a sociological reading of the 
cultural products according to which he explores the determinants of cultural production within the cultural field. In that sense, which creates the creators and what makes a cultural product a cultural product is crucial for him. As mentioned above, the cultural field determines the meaning of the product, the image of the producers, or, more generally speaking, the characteristics of the product and producer. However, the cultural field does not mechanically determine the product and producer.

Thus, although he emphasizes the structural determinants of the field of culture on products and producers, the agents have a constituting role for the structuration of the field. So, Bourdieu makes room for the change in the field. In this context, the field's characteristics emerge due to the interaction between the positions and dispositions or habitus of a producer. There can be given positions, but every new element of the field may change them. The agents from producers to receivers reproduce the positions or the newcomers of the field and can be in opposition to the positions to construct new positions. The producer must construct a belief in other agents' eyes from receivers to other powers such as art critics for making a place in the field. So, the existence of an artist is related to his capability to be recognized. In other words, artists must consider the strategic possibilities that can be read as the ways emerging in-between the artist's positions and dispositions, which is the expression of the habitus. Thus, some of the artists maintain the traditional positions that are dominant in the field; some others strive to construct new positions because their dispositions can contradict the field's rules. In that sense, the change emerges from newcomers struggling to construct newposition takings in the field. Accordingly, the boundaries and the structure of the field is constantly changing, and the field is a complex space.

The field of power is a field of latent, potential forces which play upon any particle which may venture into it, but it is also a battlefield which can be seen as a game. In this game, the trump cards are the habitus, that is to say, the acquirements, the embodied, assimilated properties, such as elegance, ease of manner, beauty and so forth, capital as such, that is, the inherited assets which define the possibilities inherent in the field. These trump cards determine not only the style of play, but also the success or failure in the game of young people concerned...(Bourdieu, 1993: 149-150). 
These ideas make apparent that Bourdieu's sociology of culture demystifies the prevalent ideas. These consider the artists charismatic being celestial creator and unique and exotic person. However, taking an artist not isolated from external forces in the field, Bourdieu includes the other agents in the process of the production and creation of meanings, styles, and discourses of artwork. In this way, he defines the ontological status of artists and artwork according to the determinants of the field. In that sense, he emphasizes the relationship between receiver and artist. In this relationship, the crucial element is the belief, which makes an artist recognized in the eyes of receivers and other agents of the field. On the one hand, there are artists; on the other hand, there are receivers. He mentions not only the artist's disposition but also the receiver's disposition in the process of receiving. Therefore, he writes about the construction of the perceptional states and habitus of the receiver. Any form and content of any cultural product are related to the producer's position-taking and position in the cultural field according to the dialectical relationship between habitus and structures of the field, which determines the producer's possibilities. An artist chooses one of the strategic possibilities to become a producer in the field. Therefore, any artist's styles, contents, and discourse are the construction of the power struggles in the field. In other words, all the products and expressions and their characteristics in the field is the effect of the forces in the field. His views on the cultural field are in harmony with his strategy to make the aesthetics the product of social, including power relations against the ideas that make aesthetic choices and expression as ahistorical, neutralized, and naturally given properties. In parallel to that, he tries to reveal the social determinants of the aesthetic choices in Distinction. Thus, the next section deals with the consumption of cultural products.

\section{The Consumption of Cultural Products: Doxa, Class, Taste and Distinction}

For Bourdieu, like every human action, the aesthetic choices are the product of social determinants. In Distinction, he analyzes in-depth and details how the class backgrounds of individuals determine their preferences in consumption (Bourdieu, 
1996). In that sense, the analysis of consumption allows him to show how class backgrounds of individuals determine their preferences. However, the legitimate culture assumes that as their aesthetic choices or tastes are exempted from interests, the others' choices and preferences are due to worldly interests. In that sense, the ideological explanations functions as creating the symbolically value-laden distinctions corresponding to distinctions in actual life. In other words, the dominant culture legitimizes its position by constructing ideas that consider the dominant classes' actions inferior. Through constructing doxas which is the ground,d for assuming everything in social life as natural, the legitimate culture uses language for symbolic violence. For Bourdieu, the language is no,t neutral, but is the product of power relations. This idea is very related to his ideas on language that structuralist linguistics assumes that the langue have a transcendent nature which makes its usage neutral.

Contrary to this idea of making the language a mere medium of communication, Bourdieu tries to show how the signs and meanings are related to users' social positions. This provides Bourdieu a way to criticize the binary oppositions such as ideal and material, interestedness, and disinterestedness. All of these distinctions assume that the dominant classes' preferences are beyond the necessities of life and are thus natural as Bourdieu says that his project is to show the social grounds of the choices.

Whereas ideology of charisma regards taste in legitimate culture as a gift of nature, scientific observation shows that cultural needs are the product of upbringing and education: surveys establish that all cultural practices (museum visits, concert going, reading etc.), and preferences in literature, painting and music, are closely linked to educational level (measured by qualifications or length of schooling) and secondarily to social origin (Bourdieu, 1996: 1).

On that ground, Bourdieu's project in Distinction can be read as to show how the supposedly neutral symbolic distinctions are very related to the power relations. In that sense, he tries to show that the cultural actions and production of the cultural products are grounded upon the class differences. Thus, he objects to the substantialist mode of thought. The following sentences well summarize these points: 
The substantialist mode of thought, which characterizes common sense -and racism- and which is inclined to treat activities and preferences specific to certain individuals or groups in a society at a certain moment as if they were substantial properties, inscribed once and for all in a sort of biological or cultural essence, leads to same kind of error, whether one is comparing different societies or successive periods in the same society (Bourdieu, 1994:4).

Therefore, the distinctions are the product of the dominant classes' action to differentiate themselves from the dominated classes:

...different things differentiate themselves through what they are in common. Similarly, the different fractions of the dominant class distinguish themselves precisely through that which makes them members of a class as a whole, namely the type of capital which is the source of their privilege and the different members of asserting their distinction which are linked to it (Bourdieu, 1996:168).

In that sense, all of the differences and symbolic distinctions are related to the individuals' class backgrounds. Therefore, Bourdieu delves into the analysis of individuals' lifestyles from consumption of cultural products to the other practices of life that are seen as the marker of class distinctions. These lifestyles are the product of the tastes which can be seen as part of the habitus. The tastes make the lifestyles unitary schemes of acting because it determines the preferences of the individuals according to their class backgrounds: "Through taste, an agent has what he likes because he likes what he has, that is, the properties actually given to him in the distributions and legitimately assigned to him in the classifications." (ibid: 175). These preferences are not natural but related to the capacity to act and schemes of practice.

Taste, the propensity and the capacity to appropriate (materially and symbolically) a given class of classified, classifying objects or practices, is the generative formula of lifestyle, a unitary set of preferences which express the same expressive intention in the specific logic of the symbolic subspaces, furniture, clothing, language or body hexis (ibid: 173).

In that sense, using any language or viewing any film is based on the individuals' dispositions and capacities. Therefore, the idea that the popular classes watch only trade movies because they are fools or have vulgar preferences neglects the social determinants of the actions. That is to say that the individuals from the same 
backgrounds have a unitary lifestyle. Thus, for Bourdieu, the preferences of the individuals can be classified according to their class backgrounds, not to the symbolically constructed dualities imposed by the legitimate culture, which makes everything naturally given. For Bourdieu, the lifestyles are the popular classes that are not inferior as assumed by the dominant classes. This idea tries to transcend the binary opposition between high and low culture in which the first is supposed as the expression of transcendental aesthetic values, and the later is supposed as intertwined with worldly interests. Thus, Bourdieu tries to transcend the duality between high and low culture in which the latter assumed to be inferior. Instead, all of the cultural actions are nothing other than the expression and product of the class positions of the individuals. Such a stand calls attention to the constructed nature of social practices and ideas. In that sense, Bourdieu tries to criticize the doxas, which ascribes the existing social life to a natural character. In other words, Bourdieu tries to reveal the symbolic power, which is "invisible power which can be exercised only with the complicity of those who do not want to know that they are subject to it or even that they themselves exercise it." (Bourdieu, 1991: 164).

As a result, For Bourdieu, the tastes of different classes that operate through lifestyles are the class backgrounds' product. In that sense, the tastes of the individuals producing the unitary lifestyles determine the forms and contents of the cultural practices. These tastes emerge as differentiated in the social space according to the different social positions. Therefore, tastes are the product of the internalization of social positions and the habitus of individuals determining their expression. Given these, through analyzing lifestyles as consisting of consumption processes of cultural products, Bourdieu reveals the class nature of taste, which is very parallel to his strategy to historicize and socialize aesthetics and language. Thus, for Bourdieu, social change is related to going beyond the doxas and its correspondence in life. Therefore, any social action, which doesn't go beyond the given and naturalized position, only reproduces the system. In other words, as long as the consumption of any cultural product is through the given schemes of action and perception, the only reproduction is nothing other than 
the reproduction of the objective structures. The habitus as involving dispositions of the individuals which, is the internalization of the objective structures, determines the action and perception of the individuals: Because, "the habitus is both the generative principle objectively classifiable judgments and the system of classification (principum divisons) of these practices." (Bourdieu, 1996: 170). Although the habitus of individuals opens a space for the agents, the habitus determines the individuals' chances. For example, it is very difficult to become a lover of any dominant class member for any member of the lower class person. Even if they confront each other, the persons cannot create a different relationship because of their different dispositions; because they differently direct to live.

\section{Conclusion}

As seen, for Bourdieu, the actions and ideas of the individuals are the social product that assumes the dialectical relationship between agent and objective structures. His ideas analyze the positions of the structures and some forms of social life. He considers them as the expression of the naturalized positions. However, although he tries to open a space for social change through habitus by generating dispositions that can lead individuals to search for strategic possibilities in a social space to create new positions, these new positions emerge within the boundaries of the social space determined by the oppositions. In that sense, any change in the social field cannot go beyond the game rules. Thus, the only change comes through going outside the game. In the context of cultural production and consumption, it becomes apparent that the individuals reproduce the given lifestyles if they come within the system. Any different taste emerges within the consumption processes emerge as the marker of the individuals' positions as the product of the dialectical relationship between habitus and objective structures. Every new action is due to differentiate itself from the others, thus oppositionally emerge. Thus, the differences produce each other creating objective structures within the social field. 
In that sense, although Bourdieu mentions different schemes of perception and action because these schemes and perceptions are socially constructed within the social field, they are nothing other than the expression of given structures and objective rules. In that sense, he is very different from de Certeau in the sense that de Certeau views a possibility to change the given structures in the consumption of cultural products. However, as mentioned above, for Bourdieu, these consumption processes only reproduce the system. Thus, for Bourdieu, there can be strategic possibilities to change the given structures within the system; the habitus of individuals determines these strategic possibilities. In that sense, these strategic possibilities do not offer to go beyond the given paroles. For Bourdieu, any different ways of living or using different parole cannot exist outside the objective structures. Because the individuals are born into a society, and in the beginning, they obey the rules of the game to exist in society. Therefore, even if he tries to open a space through the insertion of agents into the society because the agents are the product of the structurally constructed unconscious processes, their fates are determined. The structured disposition of the agents is subjected to the play of the forces in the field that may change the rules and ways of the actions in a field. On the other hand, for Bourdieu, the habitus of individuals and the rules of fields are open to change. Even though the social fields have rules and preexisting schemes of actions, a newcomer in a field and society can contribute to the change them. However, Bourdieu's sociology isn't interested in how the social changes, but how the constants in the social emerge. Therefore, his ideas concentrate on the firm and structured social institutions and actions. This perspective makes his sociology to overlook the possibilities for the change in society. 


\section{BIBLIOGRAPHY}

ADORNO, T., \& Horkheimer, M. (2002). Dialectic of Enlightenment: Philosophical Fragments. Stanford: Stanford University Press.

ALTHUSSER, L.(2014). On the Reproduction of Capitalism: Ideology and Ideological State Apparatuses. London: Verso.

BOURDIEU, P. (1990). The Logic of Practice. Stanford: Stanford University Press.

BOURDIEU, P. (1991). Language and Symbolic Power, Cambridge: Polity Press.

BOURDIEU, P. (1993). The Field of Cultural Production. New York: Columbia University Press.

BOURDIEU, P. (1995). Outline of a Theory of Practice. Cambridge: Cambridge University Press.

BOURDIEU, P. (1996). Distinction. New York: Routledge.

BOURDIEU, P. (1998). Practical Reason: On the Theory of Action. Stanford: Stanford University Press. Press.

BUTLER, J. (1997). The Psychic Life of Power. California: Stanford University

CERTEAU, M. (1988). The Practice of Everyday Life. Berkeley, Los Angeles: University of California Press.

DEBORD, G. (1995). The Society of Spectacle. New York: Zone Books.

DELEUZE, G., Guattari, F. (1987). A Thousand Plateaus. Minneapolis: University of Minnesota Press.

DELEUZE, G., Guattari, F. (2000). Anti-Oedipus. Minneapolis: University of Minnesota Press.

FOUCAULT, M. (1977). Discipline and Punishment: The Birth of Prison. New York: Vintage Books.

FOUCAULT, M. (1980). Power/Knowledge: Selected Interviews and Other Writings, 1972-1977. New York: Pantehon.

GRAMSCI, A. (2003). Selections from the Prison Notebooks. London: Lawrence and Wishart.

LEFEBVRE, H. (1991). The Production of Space. Oxford: Blackwell.

LEFEBVRE, H. (2008). Critique of Everyday Life. London; New York: Verso.

LUKACS, G. (1988). Estetik. İstanbul: Payel Yayınları.

LUKACS, G. (1962). The Historical Novel. London: Merlin. 
Recep AKGÜN. "Pierre Bourdieu's Theory of Culture and the Possibility of Social Change," Kaygl, 19(I1)/2020: 590-610.

LUKACS, G. (1963). The Meaning of Contemporary Realism. London: Merlin.

SAUSSURE, F. (1966). Course in General Linguistics. New York: MacgraveHill Book.

VOLOSHINOV, V. N. (1973). Marxism and the Philosophy of Language. New York: Seminar Press. 